\title{
Learners' perceptions of being identified as very able: insights from Modern Foreign Languages and Physical Education
}

Article

Accepted Version

Graham, S., MacFadyen, T. and Richards, B. (2012) Learners' perceptions of being identified as very able: insights from Modern Foreign Languages and Physical Education. Journal of Curriculum Studies, 44 (3). pp. 323-348. ISSN 1366-5839 doi: https://doi.org/10.1080/00220272.2012.662525 Available at https://centaur.reading.ac.uk/26199/

It is advisable to refer to the publisher's version if you intend to cite from the work. See Guidance on citing.

To link to this article DOI: http://dx.doi.org/10.1080/00220272.2012.662525

Publisher: Taylor \& Francis

All outputs in CentAUR are protected by Intellectual Property Rights law, including copyright law. Copyright and IPR is retained by the creators or other copyright holders. Terms and conditions for use of this material are defined in the End User Agreement. 


\section{CentAUR}

Central Archive at the University of Reading

Reading's research outputs online 
Learners' perceptions of being identified as very able: insights from Modern Foreign

\section{Languages and Physical Education}

Suzanne Graham, The University of Reading

s.j.graham@reading.ac.uk

Tel: +44(0)118378 8838

Fax: +44(0)118378 8810

Tony Macfadyen, The University of Reading

t.m.macfadyen@ reading.ac.uk

Tel: +44(0)118378 5895

Fax: +44(0)118378 8810

Brian Richards, The University of Reading

b.j.richards@reading.ac.uk

Tel: +44(0)118378 8838

Fax: +44(0)118378 8810 


\section{Biographical notes}

Suzanne Graham is Professor of Language and Education at the University of Reading's Institute of Education, Bulmershe Court, Earley, Reading RG6 1HY UK; e-mail:

s.j.graham@reading.ac.uk. Her research interests include language learning motivation, second language listening comprehension and language learner strategies, areas in which she has authored a number of articles and books.

Tony Macfadyen is Senior Lecturer in Education at the University of Reading's Institute of Education. He is author and editor of two highly regarded books on Physical Education and has written articles on Physical Education and $\underline{S} s p o r t s ~ S c i e n c e$

Brian Richards is Emeritus Professor of Education at the University of Reading's Institute of Education. He is author and editor of numerous books and articles on second language teaching and learning, first language acquisition, and language testing and assessment . 


\title{
Learners' perceptions of being identified as very able: insights from Modern Foreign Languages and Physical Education
}

\begin{abstract}
While learners' attitudes to Modern Foreign Languages (MFL) and to Physical Education (PE) in the UK have been widely investigated in previous research, an under-explored area is learners' feelings about being highly able in these subjects. The present study explored this issue, among 78 learners (aged 12-13) from two schools in England, a Specialist Language College, and a Specialist Sports College. Learners completed a questionnaire exploring their feelings about the prospect of being identified as gifted/talented in these subjects, and their perceptions of the characteristics of highly able learners in MFL and PE. Questionnaires were chosen as the data collection method to encourage more open responses from these young learners than might have been elicited in an interview. While learners were enthusiastic about the idea of being highly able in both subjects, this enthusiasm was more muted for MFL. School specialism was related to learners' enthusiasm only in the Sports College. Learners expressed fairly stereotypical views of the characteristics of the highly able in MFL and PE. The relevance of these findings for motivation and curriculum design within both subjects is discussed.
\end{abstract}

Keywords: Modern Foreign Languages; Physical Education; giftedness; ability; motivation.

\section{Background}

Issues of student uptake and motivation in Modern Foreign Languages (MFL) and Physical Education (PE) have been areas of interest for researchers in England for some time, albeit for different reasons. In MFL, there is a substantial body of literature seeking to understand and explain reasons for low and decreasing levels of motivation for the subject among 
secondary age learners in England, dating at least from the 1990s. Currently, the National Centre for Languages in England (CILT, 2009) reports that only $44 \%$ of 16 year olds are entered for the national examination taken at 16 (the General Certificate of Education, the GCSE) in a foreign language, and comments that in spite of various measures introduced by government to address the issue, 'there is little sign yet of a recovery in take up for languages'. Figures for GCSE language entries in 2010 show further decreases in numbers, especially for French, which is no longer in the top ten most widely taken subjects for GCSE, with a fall of $48 \%$ since 1999. England shares these difficulties in uptake of language study among older learners with other English-speaking countries, for example the USA (Lambert, 2001) and New Zealand (McLauchlan, 2006, cited in McLauchlan, 2007). _PE by contrast, although taken as a GCSE in England by a smaller percentage of pupils than is the case for MFL, has seen a rise in popularity, from 123,958 GCSE entries in 2002 to 166,930 in 2008 (Gill, 2010), although 2010 did see a 9\% decline in entries (The Guardian, 2010). The subjects also contrast in the sense that uptake of MFL among females is higher than among boys (in 20010, 178,595 girls sat GCSE French, German or Spanish, compared with 136, 899 boys), while boys tend to dominate in PE GCSE statistics (in 20010, almost twice as many boys $(80,195)$ as girls $(43,712)$ took a GCSE in PE (JCQ, 2010).

These differences in uptake are matched in part by differences in the image commonly associated with each subject. Research suggests that MFL has a 'boffer' image (Bartram, 2006, p.49), or is associated with being 'square', because of its perceived difficulty (O'Reilly Cavani, 2000, p.36). A current, influential theory of second/foreign language learning motivation suggests that an important element in heightened motivation involves the learner having an 'ideal self' image that includes the ability to speak a second language (Dörnyei, 2005). While the 'ideal self' is arguably less important for younger, adolescent learners, as 
their self-image is not yet fully formed (Kormos \& Csizér, 2008; Lamb, 2011), if language learning has negative image connotations for learners in England, then the ability to speak a language is unlikely to form part of their 'ideal self'. This stands in contrast to how language learning may be perceived in non-Anglophone countries, where being a successful language $\underline{\text { learner is more closely associated with being able to access employment, travel and poular }}$ culture. PE by contrast seems, overall, to be viewed as a 'fun' subject (Smith and Parr, 2007) which is popular with many students (Bailey and Dismore, 2004, Fairclough, 2003) perhaps because they inherently enjoy being active in interesting activities and enjoy the social aspect of taking part in physical activity (Dyson , 2006). Research by Smith and Parr (2007) found evidence that pupils' experiences of core Physical Education provided them with a break from academic study (echoing the findings of Thorbur and Collins, 2006) which has led Green $(2009$, p.20) to conclude that 'it seems that primary and secondary aged pupils view $\mathrm{PE}$ as essentially recreational' and tend to view PE as 'a radically different subject to others', in some ways because it takes place outside the 'normal' classroom. far as it... This does not mean that learners see it as unimportant, with research indicating that the opposite is the case (Dismore, Bailey and Izaki, 2006). In particular, Furthermore,-physical competence can provide a student with capital that has cultural value (Evans, 2004); similarly physical skill level can be an important status characteristic for young people (Brock, Rovegno and Oliver, 2009, Portman, 1995, both studies investigating attitudes towards sport in the USA)-

The official terms applied within the official curriculum in England to being especially able in each subject also differ, perhaps reflecting variation in-our perceptions in that context of what it means to be 'able' in each subject. The very able in language learning (and other 'academic', 'statutory' subjects including English, Mathematic, Science, etc.) are considered 'gifted', while those in PE, Art and Music are termed 'talented' (DfEE, 2000). Elsewhere in 
official documentation gifted/talented learners are defined as 'those who have one or more abilities developed to a level significantly ahead of their peer group (or with the potential to develop these abilities)' (DCSF, 2008, p. 1), with schools required to identify learners meeting this criterion and to address their needs accordingly. Although there is much $\underline{\text { confusion surrounding precise definitions of both 'gifted' and 'talented' and how they might }}$ differ (Bailey et al, 2008), 'gGifted' may perhaps have has-connotations of learners being somehow endowed with a special aptitude (Freeman, 1998); 'talented' seems to emphasise the performative aspects of PE and perhaps an element of competition.

In terms of their position within the curriculum in English secondary schools, the two subjects also differ. Since 2004 learning a language has been compulsory only up until age 14 in England. PE is also an optional examination subject post-14, but remains part of the curriculum throughout the secondary phase. It thus has a dual status within the 14-16 curriculum as something all learners must undertake at school, but which can also be selected for further study with a qualification attached to it. In addition, uptake for the two subjects is differently related to factors of social class, school type and pupil levels of attainment. Uptake for MFL is considerably higher among students of overall higher levels of attainment, who attend independent (fee-paying) or grammar schools (schools which select pupils in the basis of high academic ability generally), and in schools with low levels of deprivation. While PE uptake is lower in independent/grammar schools than it is in comprehensive (non-selective, public) schools, the discrepancies are less large than they are for MFL, and uptake is more evenly spread across the ability range (Vidal Rodeiro, 2007, 2009). 
Beyond these differences, however, there are a number of similarities between the two subjects in terms of questions of learner motivation and attitude. Both may be regarded as highly performative in nature, involving fairly 'public' displays of how well learners have mastered what has been taught in the lesson. In research on language learning across a number of contexts, the high levels of anxiety often experienced by learners, particularly in oral/aural communicative tasks, has been well-documented (e.g. MacIntyre and Gardner, 1994, Young, 1990). Bartram (2006), citing Walqui (2000), argues that this performative aspect can lead to negative attitudes towards language learning. In PE, Yli-Piipari et al $(2009$, p. $\div 328)$ comment that lessons can ' trigger negative feelings such as anxiety because of their comparative, competitive and evaluative nature', adding that elements of competition can add to anxiety among learners 'regarding their level of competence relative to their peers'. This view is not incompatible with the argument that PE is seen by many learners as 'recreational' (Green, 2009, p.20); even in such circumstances pupils may still feel 'on show', perhaps because of the 'status' aspect of the subject referred to earlier.

Likewise, both are subjects which are commonly perceived as requiring some kind of innate aptitude, gift or talent for success to be possible. Bailey (2007, p.370), citing (Gagné and Nadeau,_(1985), comments that the view that PE talent is inborn ' is an extremely widely held view among coaches and teachers', but adds that this view is less widely held among able athletes themselves, who view 'practice, parental support and mental toughness' (Bailey, 2007, p.370, citing Durand-Bush and Salmela, 2002) as more important. In language learning, language aptitude is a widely-researched construct (e.g. Robinson, 2005), but about 
which there is little consensus, particularly with regard to whether it is a fixed, unchanging quality inherent to learners or whether it can be developed (Sáfár and Kormos, 2008). Smallscale research we have conducted suggests that it is not uncommon for teachers to discuss learners' suitability for language study in terms of 'giftedness', i.e. as something innate and thus relatively unchanging. Ortega (2010) comments that teachers feel a sense of powerlessness in relation to aptitude, viewing it as 'genetic', linked to 'intelligence', 'fixed', and as 'either or' - 'either one has it, or one doesn't', although empirical evidence for such an assertion is lacking.

In terms of what language learners themselves feel about ability or aptitude, again there is relatively little research evidence. A few studies into learners' beliefs about language learning have been conducted using an instrument developed by Horwitz (1988), the Beliefs about Language Learning Inventory (BALLI) which touches on the concept of language learning ability, through an item that asks respondents whether they believe that 'some people have a special ability for learning foreign languages'. Horwitz (1999), reviewing a range of studies in different learning contexts, suggests that across investigations learners show general agreement with such a statement. Ability in language learning is also associated with general high intelligence by learner respondents in a number of BALLI studies (e.g. Peacock, 2001). Studies within England suggest, in addition, that secondary school-aged language learners tend to attribute any lack of success they experience to ability factors (Graham, 2004, Williams et al, 2004), and that perceived proficiency declines over time among this population (Williams, Burden and Lanvers, 2002).

Perceived competence is of course an important factor in all areas of endeavour. It may possibly, however, be especially important for subjects like PE and MFL, because of their 
performative characteristics and the perception that 'doing well' in these areas is related to

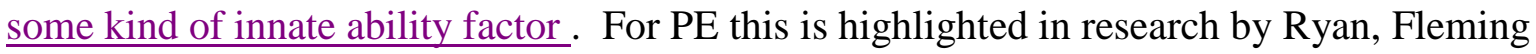
and Maina (2003) among pupils aged 15-16 in England and the USA who found that perceived competence was central to how much students enjoyed the subject. Research by Biddle et al (2005) found girls' perceived competence was highly significant in their withdrawal from sport. Likewise, one of the most important reasons for discontinuing with language study post-16 in England (at a time when it was compulsory to take a GCSE in a language) was low perceived competence, according to a study by Graham (2004). Top grades at GCSE are reported to be especially difficult to obtain in MFL, in comparison with other subjects (Dearing and King, 2007).

A number of studies have argued that academic ability is socially constructed, and that learners' views of what ability is tends to be influenced by factors such as classroom and learning organisation (e.g. Kurtz-Costes et al, 2005). Working within a theoretical framework based on notions of naive theories of intelligence (e.g. Cain and Dweck, 1995) and on research into culturally-related attributions, Kurtz-Costes et al (2005) compared learners of kindergarten, second, fifth, and eighth grade ages in the USA (where ability grouping and high stakes test at an early age are fairly rare) with those in Germany (where tests from primary school onwards are used to place learners in different schools according to their 'ability'). US learners were more likely than their German counterparts to believe that ability is not fixed but can be 'increased' through effort, with the German learners tending to see high effort as a sign of low ability. The authors interpret this with reference to the early messages German learners receive as to whether they are 'able' or not and the implications these have for their future academic success, i.e. if they are not directed to the 'Gymnasium' or grammar school stream then their chances of academic success are more limited. In the 
USA, they argue, by contrast, there is a stronger culture of belief that everyone can succeed and that the opportunity to attempt academic success remains open throughout one's lifetime. There is also a large body of research (e.g. Nicholls, 1978, supported by the Kurtz-Costes et al 2005 study) that indicates that as learners grow older (i.e. after the primary phase of schooling), they see the relationship between effort and ability differently from how younger children do, judging that the more able one is, the less effort is needed, and vice versa. This is particularly the case in Western cultures.

Other influences on notions of ability are explored by Hamilton (2002), who conducted case studies of four schools (two maintained or public, two independent) in Scotland. Citing work by Rosenholtz and Simpson (1984), she takes the perspective that pupils' conceptualisation of ability is highly influenced by the conceptualisation of the construct transmitted by the school, which in turn is influenced by the view of ability held by society. However, the latter may encompass contradictions and 'may not reflect a consensual view of ability' (Hamilton, 2002, p.592). Hamilton's study looks at learners from the first years of secondary school, across the subject areas of mathematics, English, music and art, and investigates their beliefs about their own ability, their conceptualisation of high ability, and their 'understanding of a possible institutional model of ability as mediated by the teacher' (p. 596). While learners in the first year 'were most likely to conceptualise high ability (...) in relation to an evaluation characterisation' (p. 597), i.e. in terms of personal strengths and weaknesses, by the fourth year, particularly for learners in maintained schools 'their personal notions of ability (selfdefinition) moved away from the evaluative stance and began to reflect gradings and comparative positions in setted and broad-banded classes' (p.597). That is, constructions of ability became more externally based and norm-referenced, although learners retained an 
element of internal referencing. In spite of interviewing pupils about four distinct subject areas, Hamilton offers no insights about whether ability constructions differ across subjects.

Looking specifically at PE, Evans and Penney (2008) argue that how ability in PE is construed in England has changed over the years. They compare the 1952 and 1999 curriculum documents for England, commenting on the extent to which 'performative' notions of ability permeate the latter (a conclusion also drawn by Backman, (2011) in relation to the PE curriculum in Sweden). Evans and Penney (2008, p.181, citing Hunter, 2004) further comment on discussions of how the image of the 'good' pupil (their term) in PE 'is shaped by characteristics of competence, competition, comparison, display, skill, and fitness, especially within a context of PE as sport'. They go on to argue that such a view results in a pedagogy that 'predicates a social order characterised by “-vertical hierarchies"”, in which individuals are ascribed positional status by virtue of how well they can perform. Each learns the relative un/importance and potential immutability of their own and others" "-ability"-- as well as their allocated or achieved social role (...) children inevitably learn to assess their ability not with reference to their inherent potential or “-educability"-, or how good "_-movement feels"-- but to how others define, judge and value their performances displayed in a variety of pre-defined activity forms and according to externally defined norms and ideals.' (Evans and Penney, 2008, pp. 4243).

Notions of talent in PE are littered with conceptual difficulties which means talent identification can be problematic for PE teachers (Bailey, Tan and Morely, 2004, Bailey and Morley, 2006), with many basing judgements on current achievement (e.g. learners arei.e. 
chosen for school teams) rather than on potential (Bailey et al, 2004, Bailey, Morley and Dismore, 2009), and overlooking non-physical characteristics in learners that can contribute to 'talent' such as 'cognitive, personal, interpersonal and creative aspects' (Bailey et al, 2004, p. 65). Not surprisinglythen, many researchers in PE (e.g. Flintoff and Scraton, 2006, Talbot, 1996) have commented on the difficulty of certain groups such as girls to fit in, let alone excel, in the subject given how the traditional PE curriculum privileges team games (OFfSTED, 2005), and values orthodox masculinity (e.g. demonstration of physical vigour; aggression) that run counter to many girls' conceptions of their physicality and appropriate feminine appearance (Cockburn and Clarke, 2002) Other authors (e.g. Barton, 1993, p.49) have argued that $\mathrm{PE}$ 'is the creation of an able-bodied people [which] gives priority to certain

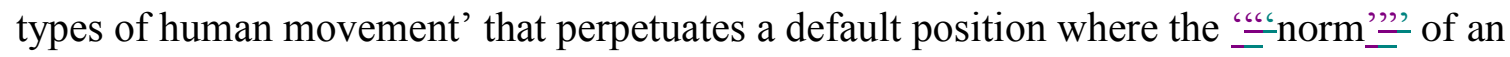
able learner in PE is an athletic, able bodied, white middle class male. Penney (2000) has argued that conceptions of 'excellence' within PE are usually associated within a discussion of performance in sport that again militates against certain groups doing well.

Discussions of what it means to be 'able' in language learning tend to be carried out within

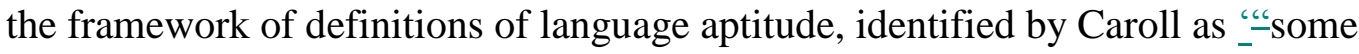
characteristic of an individual which controls, at a given point of time the rate of progress that he will make subsequently in learning a foreign language"'- (Caroll, 1974, quoted by Sawyer and Ranta, 2001, p.: 310). Carroll (1981, p.105) identified four components of language

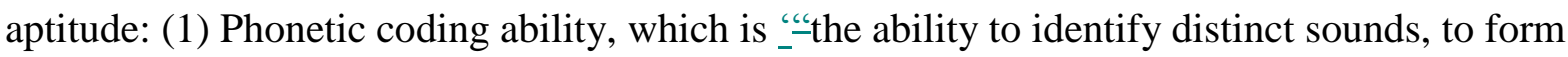
association between those sounds and symbols representing them, and to retain these associations"'” (p.105), (2) grammatical sensitivity, meaning the ability "“"to recognize the grammatical functions of words (or other linguistic entities) in sentence structures"' (p. 105), (3) rote learning ability, defined as "- the ability to learn associations between sounds and 
meanings rapidly and efficiently, and to retain these associations"'- (p. 105), and (4) inductive language learning, the ability ${ }_{-}^{\text {' }}$ to infer or induce the rules governing a set of language materials, given sample language materials that permit such inferences"” (p. 105). Such a model, however, has been criticised for only reflecting aptitude in relation to a certain type of language learning involving grammatical analysis and formal, less communicative language learning (see Krashen, 1981, for example), indicating that as for PE, 'ability' in language learning is also context-dependent . Likewise, in terms of how 'doing well' in languages is viewed within the context of the research described in this article, Mitchell (2003) comments that the National Curriculum level descriptors for England (a set of proficiency indicators) lay heavy emphasis on increased accuracy as a marker of 'doing well' in language learning, which, she argues, has little basis in theoretical terms regarding what direction progression in language learning really takes.

In addition to examining how high ability is conceptualised within society as a whole, it seems important to explore also how learners feel about being highly able, whether they see it in a positive or negative light, something which a range of studies have aimed to do (although few have taken a subject-specific perspective). Overall, the picture seems to be a mixed one. For example, Kerr, Colangelo and Gaeth (1988) looked at 184 gifted adolescent learners' feelings about their giftedness, and how they felt it was perceived by others (the modal age of learners was 16). While the learners themselves felt positively about their giftedness, they felt others did not see it in this way. They were also less positive about their giftedness in terms of social factors. In a partial replication of that study, Manaster et al (1994) delved more deeply into how 144 gifted learners (aged 15-16) felt about their specific gift. Like Kerr et al (1988), they used an open-ended questionnaire, asking questions such as 'What does the term gifted mean to you?' 'In what ways are you unlike most other students in your 
school?' (Manaster et al, 1994,p.: 177, emphasis in the original). They were also asked about the best and worst thing about being gifted. The highest percentage of responses (53\%) for the best thing referred to social advantages (different from the respondents in Kerr et al's (1988) study, only $29 \%$ of whom said social elements were the best thing). At the same time, $87 \%$ of respondents also said that social aspects were the worst thing about being gifted.

Fewer studies have compared the views of gifted and non-gifted learners. One study by Udvari and Rubin (1996) investigated whether school children rated more positively high academic achievement, academic effort, or athleticism, comparing the views of gifted and non-gifted learners (123 in total, aged between 8 and 12 years, with 62 gifted and 61 nongifted learners). For all learners, and especially older learners, athleticism was associated with sociability and attractiveness, but so was high academic achievement (especially among gifted learners, who were also more positive towards athleticism). There seemed to be no positive or negative association with being studious or non-studious by either group. The authors comment that 'It appears that as children enter adolescence, participation in athletics gains importance in perceptions of social acceptability' (Udvari and Rubin,1996, p. 216).

How those not formally identified as gifted feel about the prospect of being so identified is a question that, to our knowledge, has not been explored. Would such identification be welcomed by learners? Such a question seems of particular interest in relation to subjects like MFL, where research has indicated that learners' disaffection with the subject stems in part from their lack of perceived achievement in it (Graham, 2004) and their sense that it is a difficult subject (QCA, 2006). Would learners feel differently about the subject, if they were told they were good at it? Or would the image factors associated with the subject discussed above still discourage learners from liking the subject? For PE, while also being a subject 
which learners may feel requires a special talent to do well, there may be a sense that such a 'talent' is a more desirable thing to have. In addition, to what extent are school values transmitted to pupils about the value of achievement in different subject areas? In England, it is common for secondary schools to have a 'specialism', that is, to choose an area of the curriculum in which they seek 'to establish distinctive identities through their chosen specialisms and achieve their targets to raise standards. Specialist schools aim to develop centres of curriculum excellence which are catalysts for accelerated whole school improvement by making a step change in the way they develop educational provision and raise standards for all students' (DFES, no date). The extent to which attending a school with a specialism in either languages or PE/Sport influences learners' perceptions of being gifted/talented in that area also seems worthy of exploration, as one might expect learners to attribute higher value to the specialism promoted in their school. In addition, for schools with a language specialism, studying a language post-14 is compulsory, so it is possible that this might add to the sense of 'value' for the subject conveyed to learners (see Coleman, Galaczi and Astruc, 2007).

The aim of the present study was thus to gain further insights into how learners in specialist schools felt about MFL and PE by exploring learners' perceptions of being gifted/talented, through the following research questions:

1. How do learners feel about identification or the prospect of identification as gifted/talented in
a) MFL
b) PE 
2. Do learners' feelings about being gifted/talented differ across the two subjects?

3. Do learners' feelings differ according to the school's specialism?

4. What image emerges of a how learners perceive a 'successful' student in PE/MFL to be and what does this suggest about how pupils perceive these subjects in general?

We chose not to explore gender-differences in relation to the two subject areas, as these issues have been widely considered elsewhere (e.g. Jones, 2009 for MFL and Dismore et al, 2006, to name but two recent studies).

\section{Method}

\section{Participants}

Two schools were selected to be involved in the study. They were selected on the basis of having a specialism in languages or sport respectively. They were matched in terms of being both 11-18 comprehensive schools and having broadly similar levels of attainment in terms of the percentage of pupils gaining five 5 or more high level $\left(A^{*}-\mathrm{C}\right)$ GCSE grades (including English and Maths), although School A had a slightly higher percentage of pupils reaching this benchmark at the time of the study (50\%) than School B (39\%). In School A, 50\% of pupils reached this benchmark at the time of the study, while in School B the figure was 39\%.

Each school was approached and permission for the study to take place granted by the Head Teacher. We requested access to one tutor group in Year 8 (i.e. second year of secondary education, aged 12-13) from both schools, to give a similar size group in each school and which would be made up of learners of mixed ability in terms of PE and modern languages. The group in School A consisted of 43 learners, in School B of 35 learners, giving a total sample size of 78. In terms of learners who had in fact already been identified as highly able in either subject (as indicated by their responses to one of the questionnaire items, see below 
and Appendix), across these Year 8 pupils in the two schools $16(21 \%)$ learners had been thus identified for MFL, and 29 for PE (37\%), as ascertained from their subsequent questionnaire respenses. Nine of the 16 'gifted' MFL learners were from School A, seven from School B, and for PE the split was 13 'talented' learners for School A, 16 for School B. Thus a slightly higher percentage of learners in School A (67\%) had been identified as gifted/talented in either subject compared with School B (57\%).

\section{Instruments and procedures}

\section{The questionnaire}

In order to gain a broad perspective of pupils' perceptions of being gifted or talented, we chose to use a questionnaire to gather data. This allowed us to reach a larger sample of learners than interviews would permit. We also felt that learners of this age group would be more likely to respond positively and openly to an anonymous and short questionnaire. No $\underline{\text { background details (e.g. sex) were requested from learners at all, to help to maintain this }}$ sense of anonymity.

Fifteen questionnaire items were selected in order to tap into pupils' feelings about being gifted or talented (see Appendix). Questions 1 and 3 asked them to select from a range words which might convey how they would feel about the prospect of being identified as gifted/talented in MFL and PE respectively. Given the lack of research into perceptions of high ability in PE and MFL, we were not able to draw directly on any study in selecting these words. We did, however, draw on the findings of a number of previous studies into learners' more general feelings about the subjects (e.g. Bartram, 2006, Graham, 2004, O’Reilly Cavani, 2000, for MFL, and Bailey and Dismore, 2004, Fairclough, 2003 for, PE) Z ... to 
generate words. These were then piloted with a small group of secondary school learners

(from schools not involved in the study), who commented on their clarity and

appropriateness. In the main study, learners were also free to add a word or phrase of their own, and were asked to explain their selection of the one word which best conveyed how they felt (Qs 2 and 4). We also wanted to explore learners' sense of how important it would be to them to be identified as gifted/talented in each subject (Qs 5-8). Additional questions were designed to gain insights into pupils' feelings about actually being identified or not as gifted/talented in each subject (Qs 9-12); thus this group of questions began by asking pupils whether they had in fact already been so identified by their current school. Finally, and in order to address our fourth research question, we asked learners to list what they thought were the characteristics of someone who was gifted/talented in MFL or PE (Qs 13 and 14).

The questionnaire was piloted with a small group of similar learners, the clarity of each item discussed with them and their responses analysed for any potential misunderstanding.

The final questionnaire was completed by learners from Schools A and B during their tutor period. It was administered by their form tutor who was asked to place completed questionnaires straight away in a sealed envelope for return to the researchers. By not involving languages or PE teachers in the administration of the questionnaire, we hoped that learners would feel more able to reply honestly. Each learner gave informed consent for the use of their questionnaire in the study.

\section{Analysis}


Data were entered into SPSS, from both the closed and the open items. The words circled by each respondent for Questions 1 and 3 were recorded and frequencies obtained for each word. Individual pupils' responses were also examined and the respondent coded as having an overall positive attitude towards the idea of being identified as gifted/talented. Where the respondent displayed mixed feelings, it was in most cases still possible to decide on an overall orientation; if this was not possible (because the respondent gave positive and negative words in equal number), then the word they identified as best summing up their feelings was taken as the deciding factor. In both cases the equivocal nature of their feelings was noted. Reasons learners gave for choice of words as the most important ones for them were reviewed, themes that emerged identified and then used to develop codes that were then applied to the data. Coding was carried out by the first author. To enhance the reliability of $\underline{\text { this analysis, the open-ended responses were then recoded by the first author several months }}$ later. The initial coding held good in the second round of analysis. The same procedures were followed for and coded, learners'as were reasons for the importance/lack of importance of being identified as gifted/talented in each subject. _Non-parametric statistics were used to explore whether learners' feelings about being gifted/talented differed across the two subjects and whether these feelings differed according to the school's specialism. The characteristics learners associated with being gifted/talented in each subject were typed into SPSS_and frequencies calculated.

\section{Findings}




\section{Research question 1}

1a. How do learners feel about the prospect of being identified as gifted/talented in MFL?

As outlined above, learners' responses to Question 1 were examined and each learner coded as either positive or negative towards the prospect of identification. Learners were much more positive than negative towards this idea than we had expected, with 67 (86\%) of learners showing a positive orientation, and $11(14 \%)$ a negative one. In terms of the feelings learners identified, table 1 shows how many learners circled each word for MFL and how many chose it as the word that best summed up how they felt. As can be seen, three words were identified more than any others: happy, pleased and proud, and account for $65 \%$ of the choices made for Item 1 of the questionnaire. They were also the words most frequently singled out as the one best summing up the learners' feelings. However, in terms of the reasons given for selecting the summary word (table 2), only nine (12\%) students explained their choice by referring to their interest in, or liking of, MFL. Only one mentioned being good at the subject. Most (34 out of 78) referred to a sense of achievement.

<Tables 1 and 2 about here>

Table 1 shows that the most frequently circled negative word is 'not bothered', which was also the word most often picked out as the one that summed up pupils' feelings among negative students (by 10 students). Five of the students who chose this word explained it simply by giving a paraphrase of the word (e.g. I don't care), while three made reference to 
not liking languages (the other two stating that they didn't have a reason or were in a bad mood!).

Within these broad orientations, a small number of pupils (9) displayed mixed feelings. Eight of these were mainly positive, one negative. For the mainly positive pupils, the negative feelings circled indicated mainly a sense of anxiety of some form - embarrassed, burdened, worried, although three pupils also said they were 'not bothered'. Further insights are given into this sense of anxiety where learners, although circling more positive than negative words, chose the more negative word as the one that best summed up their feelings and commented on it. Comments included the following:

- If $i$ (sic) do badly everyone will know

- I might not know what to do

- I have to live up to something

All of which indicate, perhaps, a fear of not being able to live up to expectations.

\section{1b. How do learners feel about the prospect of being identified as gifted/talented in PE?}

Pupils' reactions to the idea of being identified as talented in PE were overwhelmingly positive, with $90 \%$ of them showing a mainly positive orientation. Feelings identified are given in table 3 , showing that all six positive words were circled by at least $37 \%$ of learners. The words most often chosen as the best summing up were proud, pleased, happy and excited, as seen in table 3. When the reasons learners gave for choosing their word were 
analysed, the most popular reason was a liking of PE, given by nearly a quarter of all respondents (table 4).

<Tables 3 and 4 about here>

As in MFL, a small number of pupils expressed mixed feelings about being talented in PE, but all were mainly positive in their orientation. The negative feelings they expressed within this were embarrassed, burdened and worried, again, feelings suggesting a sense of anxiety One learner wrote 'I would feel pressure to perform well', which is reminiscent of the sentiments expressed above in relation to MFL about the fear of not living up to expectations.

\section{Research Question 2: Do learners' feelings about being gifted/talented differ across the two subjects?}

The results above indicate that learners are very positive about being identified as

gifted/talented in both PE and MFL. Indeed a cross tabulation showed that more than $75 \%$ of learners were positive regarding both subjects, with no significant difference in attitude to each subject (Fisher's Exact Test). A closer examination of learners' responses, however, in terms of the number of words circled, suggests that learners' attitudes do differ. As can be seen from tables 1 and 3, learners circled a much greater number of feelings for PE than for MFL (267 versus 197). A further analysis was conducted by giving each learner a total score for the number of feelings circled for each subject. Both the median and mode values were higher for PE than for MFL, a difference which a Wilcoxon test for related samples showed to be statistically significant $(\mathrm{z}=4.07 ; \mathrm{N}=78 ; \mathrm{p}<.001)$. It is possible that this difference suggests a greater level of enthusiasm for the idea of being gifted/talented in PE, which is also borne out by the fact that liking the subject was a much more common reason for 
choosing a positive word for this subject than it was for MFL. A higher percentage of pupils chose 'not bothered' for MFL (5.6\%) than was the case for PE (1.9\%), while the reverse was true for 'motivated' (7.1\% for MFL, $11.2 \%$ for PE), which in both cases suggests that being identified as talented in PE means more to pupils than is the case for MFL. More pupils explained their choice of word with reference to the fact that identification would spur them on to work harder in PE than was the case for MFL (5.1\% MFL, 11.9\% PE).

Further items (Qs 5 and 76) in the questionnaire probed learners' feelings about being gifted/talented in the two areas by asking them to state whether it was important for them or not that their school identified them as being gifted/talented. Table 5 shows the percentage of pupils in each subject expressing each view.

$<$ Table 5 about here>

Thus while pupils feel identification is important in both subjects, such feelings are much more muted with regard to MFL. A Fisher's Exact Test indicated that the difference in pupils' responses between the two subjects was statistically significant $(\mathrm{p}<.01)$.

Among those who in MFL thought it was important to be identified as gifted, the reasons most frequently given (Q6) were that they would be 'noticed' (22.5\%), that MFL is important $(22.5 \%)$, and that it would motivate them (17.5\%). Only one learner gave liking MFL as a reason. In $\mathrm{PE}(\mathrm{Q} 8)$, by contrast, $(\mathrm{Q} 8)$ liking the subject was the most frequently given reason (38.5\%), followed by being noticed (21.2\%) and increasing motivation (19.2\%). The importance of the subject was mentioned by only one learner. 
Reasons given for believing that identification as gifted/talented is unimportant also differed across the two subjects. In MFL, the main reasons of 'not bothered' (31\%), MFL as unimportant (17.2\%), and disliking MFL (20.7\%) suggest that a number of learners, even if they were hypothetically 'good' at MFL, would still dislike the subject and attach low value to it (especially if 'not bothered' and 'MFL unimportant' are combined). A relatively high proportion also thought that identification itself was 'unnecessary' (16\%). In PE the main reason for not feeling identification was important was that PE itself is unimportant $(37.5 \%)$, followed by identification being unnecessary $(25 \%)$, an even higher figure than for MFL.

A further question (Q10) was whether having in fact already been identified as gifted in MFL by the school made any difference to how pupils felt about the importance to them of being thus identified. As outlined above, a lower percentage of pupils had been identified in MFL than in PE. A cross tabulation showed that for MFL there was only a small and nonsignificant tendency for those identified to think it more important (compared with those not identified), and, perhaps more importantly, almost a third of those identified (five learners) did not think it was important to them to have been thus singled out (table 6)

$<$ Table 6 about here>

Of these five learners, one explained they were 'not bothered', two felt they were better at other things, one was 'not that interested', another that school as a whole didn't matter. For PE (Q12), a relatively small percentage of those identified thought it was unimportant. Their reasons suggest a certain modesty and perhaps a dislike of being 'labelled': 
- Because people should accept you for who you are

- Because it doesn't matter

- I think as long as people are praised enough they will know they are gifted and their results will show

- $\quad$ There are other girls who are more talented and gifted than me

Regarding how learners felt about having been identified or not (Items 10 and 12 in the questionnaire), as opposed to the importance they attached to this, reactions in MFL were again more mixed than they were in PE. Of those identified in MFL, 10 learners were wholly positive (happy/proud), while five were less so - two were embarrassed, one scared, two not bothered. Another simply replied that they were half French. Learners who had not been identified in MFL largely wrote that they were not bothered (23), but nine were upset or disappointed.

By contrast, all identified students in PE were positive about it, mainly pleased, excited or proud. Nine non-identified students were upset or disappointed.

\section{Research Question 3. Do learners' feelings differ according to the school's specialism?}

Learners' feelings about being identified as gifted/talented in the two subjects in School A (school with language specialism) were compared with those of learners in School B (school with PE specialism). In tables 7 and 8 School A learners show a slightly more positive 
attitude to MFL than do those in School B, while School B learners shows a slightly more positive attitude to PE. However, these differences are not statistically significant.

\section{$<$ Tables 7 and 8 about here>}

Earlier it was argued that behind the equally positive response of learners to being gifted/talented in both PE and MFL, the greater number of words circled for PE than for MFL overall indicates a more positive engagement with the idea of being gifted/talented in PE. This holds true when the responses are examined by school: even in School A, a language specialist school, learners circled more words in relation to PE than they had for MFL:

\section{<Table 9 about here>}

Table 9 also suggests that pupils in School A circled more words overall than pupils in School B. These differences are statistically significant on a Mann-Whitney test for both $\operatorname{MFL}(\mathrm{z}=2.127, \mathrm{p}=.033)$ and $\mathrm{PE}(\mathrm{z}=1.933, \mathrm{p}=.046)$, and may suggest that School A pupils weere more positively engaged with the idea of being gifted and talented than those in $\underline{\text { School B.- }}$

When the schools are compared in terms of how important learners feel gifted/talented identification is in each subject, for MFL the schools are almost identical (table 10), a surprising result, given that in language colleges, all pupils are obliged to continue language learning post-14, unlike in non-specialist schools. It is sometimes argued (e.g. Coleman et al, 2007) that making languages optional post-14 has decreased their importance in learners' eyes. Counterviews however, (e.g. Macaro, 2008), argue that learners' disaffection with language learning was widespread even when they were compulsory post-14, a view that gains some support from the current finding that optionality/obligatory study do not seem to influence the importance learners attach to being very able in the subject. 


\section{<Table 10 about here>}

For PE, however, there is a higher proportion of pupils in School B (the PE College) for whom being gifted/talented in PE is important. This result is statistically significant $(\mathrm{p}<.05)$ on a one-tailed Fisher's exact test (table 11):

<Table 11 about here>

Thus while it seems that having a specialism does not necessarily foster a greater sense of importance for language learning, the opposite may be true for PE.

\section{Research Question 4. What image emerges of a how learners perceive a 'successful' student in PE/MFL and what does this suggest about how pupils perceive these subjects in general?}

For each subject in turn, learners were asked to think of the characteristics of someone who was gifted/talented in the subject and write them down (Qs 13 and 14). Learners' responses suggest, however, that not all of them understood what was meant by 'characteristic' and may have confused it with "character". A substantial minority wrote down the names of other pupils (these have been removed from the following analysis). In other cases pupils seem to have been thinking of another pupil who was gifted/talented and to be describing them. Hence the mentions of "friendly" for both MFL and PE below - although research does suggest that younger, pre-adolescent children do in fact associate non-cognitive characteristics with being 'smart' (see Kurzt-Costes et al, 2005). Thus the following results need to be interpreted with caution. 
Coincidentally, there were 129 mentions of characteristics for both MFL and PE. Pupils did not always mention the same number of characteristics for each subject. The most frequently mentioned characteristics for MFL were "smart" (10.0\%), "brainy" (7.8\%) and "friendly" (7.8\%) If all terms indicating 'cleverness' are taken together, however, these account for $28 \%$ of responses, indicating that being good at MFL is seen largely as a cognitive skill, perhaps associated with high intelligence. Interestingly, if all terms indicating hard work or effort are grouped together, then these account for $17 \%$ of responses, suggesting that effort and ability are more closely related for this sample than one might expect from previous research among learners of this age_-(e.g. Kurtz-Costes et al, 2005). The association by some learners of hard work and giftedness is also reflected in response to other questions, e.g. Items 6 and 8, regarding the importance of being identified as gifted/talented:

- It shows that if you do well and work hard teachers and the school take notice

- yes because all my Hard work pais of (sic)

- Because it proves we work hard

- because it make you want to work hard

- yes because it makes me work harder

- Because if you do it you will feel confident and work more hard for it

It is also apparent in a final comment from a pupil from School A

Not all the times some one could be talented sometimes you have to work hard to be talented.

Noteworthy from the above is that for some learners, hard work seems to lead to $\underline{\text { identification as very able, while for others, such identification can prompt increased effort }}$ 
(perhaps through increased confidence) which then in turn may further increase attainment. These differing perspectives are returned to in the Discussion.

For PE, "Sporty" was mentioned most frequently (7.8\%) followed by "fit" (7.0\%) and "friendly" (6.2\%). If all terms related to fitness, health, strength and athleticism are combined, however, these amount to $13 \%$ of responses. Effort-related terms were used less frequently than was the case for MFL, amounting to only $5 \%$ of responses. Interestingly, however, some learners attributed cognitive ability to those talented in PE (describing them, for example, as 'brainy'), with 5\% of responses taking this form. While there were few clearly negative adjectives given for either subject, there were more for MFL than for PE (which had only one, 'annoying', compared with three for MFL - 'gay', 'show off' and 'teacher pet' (sic)).

\section{Discussion}

In response to our first two research questions, regarding learners' feelings about the prospect of being identified as gifted/talented in the two subjects, and whether these feelings differed according to the subject, we found that learners were overwhelmingly positive about the prospect. There was no statistically significant difference in terms of the numbers of pupils giving positive responses between subjects. This was unexpected and suggests that learners would like to be considered able in MFL as much as they would for PE, in spite of the more favourable image usually associated with the latter. This adds weight to the argument (Author 1, forthcoming) that the perceived difficulty of language learning is the most important factor in learners' lack of motivation for the subject. Nevertheless, in spite of this 
positive response for both subjects, there was a more subtle indication of greater enthusiasm for the idea of being very able in PE, suggested by the greater number of feelings expressed by respondents in relation to PE. Additional insights were provided by the reasons learners gave for their feelings, with far more students justifying their choice of word by saying they liked PE than was the case for MFL. A sense of achievement was an important reason for MFL, perhaps again underlining its image as a difficult, cerebral subject. Being noticed was important for learners in both subjects, perhaps underlining learners' sense that school is a competitive environment. In both subjects, a small number of learners expressed some anxiety about the prospect of being identified, with a sense that they were worried about increased pressure.

The greatest divergence between the subjects was seen in how important learners felt it was to be identified as highly able in the two subjects. Having in reality been so identified did not increase the likelihood of learners seeing identification as important for either subject. However, learners were more likely to see identification as important in PE rather than in MFL, again giving liking for the subject as the main reason. For MFL, being noticed was the main reason for importance, alongside the importance of the subject. This must be set against those who did not feel identification in MFL was important and gave reasons that reflected the generally low value they attributed to the subject, which seems to echo findings of previous, larger studies (e.g. Stables and Wikely, 1999). Strikingly, five learners who had been identified as gifted/talented in MFL did not feel such identification was important to them.

Attending a school with a language specialism had relatively little impact on learners' feelings about gifted identification for MFL. While learners at School A were more positive 
about the idea than those in School B, this was not statistically significant. This was true also of the importance they attached to identification. On the other hand, for PE, learners in school B attached more importance to identification in this subject compared with learners in School A (even though overall learners in School A showed more enthusiasm for the idea of being gifted/talented across the two subjects). Why subject specialism should seem to have a greater impact on learners' views of a subject for PE than for MFL is not clear, nor why gifted/talented identification was more 'popular' in one school than another. The latter may relate to the higher percentage of learners in School A who had been identified ( $67 \%$ versus 57\% in School B), suggesting perhaps that the notion of gifted/talented identification played at bigger role in School A than in School B, which may have influenced learners' perceptions-. It may also-relate to differences in the two schools' cultures in terms of how much emphasis is placed by each school on high attainment, and how much prominence is given in each to Gifted and Talented identification. A more in-depth study of the schools' policy and practice in these areas would be needed to gain further insights into this issue. For MFL, tThe findings do however alse contradicts those of Coleman et al (2007), whose study indicates that learners in Specialist Language colleges have more positive attitudes to language learning than those in schools without such a specialism. The present study does, however, cover a much smaller sample than that of Coleman et al (2007).

In terms of the characteristics learners associated with being highly able in the two subjects, the cognitive, cerebral aspects of language learning seemed to be at the forefront of learners' minds, which suggests that these learners associate high ability in languages with high intelligence, similar to the findings of the BALLI studies (e.g. Peacock, 2001). This focus on the cognitive aspects of language learning ignores the broader social, communicative and 
interaction-based knowledge and skills that are meant to be developed through the secondary national curriculum for MFL in England (QCA, 2007a). Effort was also relatively frequently mentioned, but not for PE, which is surprising, given the importance usually attached to regular training and practice for high achievement in sport (Bailey, 2007). For PE, the more frequent mentions of characteristics clustered around fitness, strength, health and athleticism seem to suggest that learners have taken on board the dominant image of ability in PE highlighted in the literature (Evans, 2004), and reflected in the tendency of teachers to ignore broader, non-physical aspects when making talent identification judgements (Bailey et al, 2004) $)$. Again, the secondary national curriculum for PE in England is intended to develop a $\underline{\text { range of skills in learners, including 'the ability to use tactics, strategies and compositional }}$ ideas to perform successfully. When they are performing, they think about what they are doing, analyse the situation and make decisions' (QCA 2007b). Thus for both subjects, learners seem to have acquired fairly stereotypical views of what it means to be highly able, which do not fully reflect the range of skills and attributes called upon by both subjects..-

For MFL, effort was relatively frequently mentioned as a characteristic of highly able learners, but not for PE, which is surprising, given the importance usually attached to regular training and practice for high achievement in sport (Bailey, 2007). Across both subjects, how learners perceived the relationship between effort and identification of high ability was $\underline{\text { complex, as expressed in their statements about why they would feel positive about being }}$ identified as very able. It was noted that some learners indicated that effort led to identification, others that identification prompted further effort. The first of these responses seems to be out of line with previous research findings that suggest that around about the start of secondary schooling, learners start to associate being 'smart' with achieving highly but 
with little effort (see Keogh and Whyte, 2008, p. 82, who found this to be the case among 11 year old learners in Ireland). Perhaps what the present sample of learners is expressing most strongly is a desire to have their efforts recognised and valued by their teachers ( $\boldsymbol{B}^{\prime}$ 'because it proves we work hard'). This desire also seems apparent in the other set of statements that

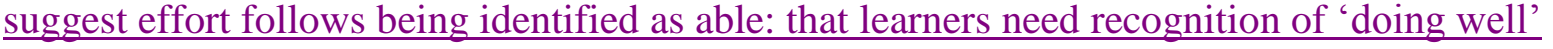
in order to commit effort to a curriculum subject.

\section{Conclusion}

This study has shed light on the attitudes of learners in England to two subject areas, Physical Education and Modern Foreign Language study, by taking a perspective which, to our knowledge, has not been previously adopted in research: namely exploring learners' feelings about the idea of being identified as very able in each subject area. It thus goes beyond previous research that has looked at learners' reasons for continuing or not continuing with these subjects beyond the compulsory phase. The fact that learners in our sample generally like the idea of being identified as very able in both subjects suggests that a sense of achievement is a key motivating factor, as one might expect. For MFL, learners were more positive about the idea than we had expected, although still less positive than they were about the prospect in PE. High ability seemed to be viewed in both subjects from a fairly stereotypical standpoint - with MFL viewed as a highly cognitive, cerebral subject, and PE associated with health, fitness and athleticism. Whether learners see these characteristics as innate and fixed, or malleable and amenable to development through effort, is a particularly interesting question, which seems to have received less attention in the context of the curriculum in England than elsewhere. Further research is needed to explore this last question 
in greater detail, as it is likely to provide further insights into learners' motivational perspectives, given that it has been argued that holding an 'essentialist' view of ability (i.e.fixed) leads to the development of more limiting performance (competition-focused) goals rather than mastery or learning goals (Cain \& Dweck, 1995)- In addition, research into teachers' views about what it means to be highly able in MFL, and further work in PE building on that of Bailey et al $(2004,2009)$, would add to the picture, with the possibility that learners' views-the fairly stereotypical image learners have of the qualities needed in each subject are a reflection of the messages that are conveyed through the school environment, and especially by what their teachers believe. Finally, further research into these issues across a wider range of curriculum subjects would enhance our understanding of learners' conceptions of ability across different domains.-

Acknowledgements: To be added post-review

\section{$\underline{\text { Appendix }}$}

This questionnaire is anonymous so please do not write your name on it.

We are interested in finding out how you feel about being identified as 'gifted' or 'talented' in

- Modern Foreign Languages (MFL); for example French, German, Spanish

- Physical Education (PE).

Please answer the following questions as honestly as you can:

1. How would you feel if the school identified you as gifted/talented in MFL? Ring the words below that describe how you would feel (you can ring more than one word) or add a word or sentence of your own in the space provided below:

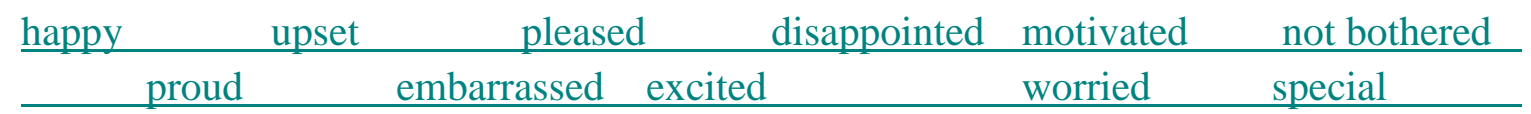
burdened 
If none of the above words are appropriate please use a word or sentence of your own:

2.Choose one word that you have used in Q.1 which best describes your feelings and explain why you feel this way

The word is:

I feel like this because

3. How would you feel if the school identified you as gifted/talented in PE? Ring the words below that describe how you would feel (you can ring more than one word) or add a word or sentence of your own in the space provided below

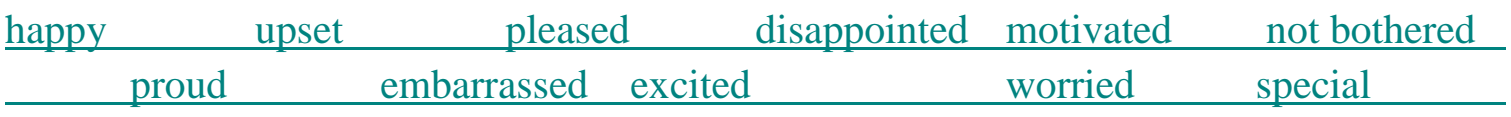
burdened

If none of the above words are appropriate please use a word or sentence of your own:

4. Choose one word that you have used in Q.3 which best describes your feelings and explain why you feel this way

The word is:

I feel like this because

5. Is it important to you to be identified by your school as being gifted / talented in MFL? $\underline{\text { YES / NO (delete one) }}$

6. Please explain your answer to Question 5.

7. Is it important to you to be identified by your school as being gifted / talented in PE? $\underline{\text { YES / NO (delete one) }}$

8. Please explain your answer to Question7.

9. Has your current school identified you as being gifted / talented in MFL? $\underline{\text { YES } \quad \mathrm{NO} \quad \text { (tick one) }}$

10. How has this made you feel? 
11. Has your current school identified you as being gifted/talented in PE? $\underline{\text { YES _ N N N _ (tick one) }}$

12. How has this made you feel?

13. Please think of the characteristics of someone who is gifted and talented in MFL and list them below

14. Please think of the characteristics of someone who is gifted and talented in PE and list them below

15. If there is anything else about gifted and talented pupils in MFL ad PE you would like to tell us about please write it below

THANK YOU for your help. 


\section{References}

Bailey. R. (2007) Talent development and the luck problem, Sport, Ethics and Philosophy, 1, $367-377$.

Bailey, R. and Dismore, H. (2004) SpinEd The role of physical education and sport in education. Project report. $4^{\text {th }}$ International Conference of Ministers responsible for Physical Education and Sport. Athens, Greece: December 6-8, 2004.

Bailey, R. and Morley, D. (2006) Towards a model of talent development in physical Education. Sport, Education and Society, 11(3), 211 -230.

Bailey, R., Morley, D. and Dismore, H. (2009) Talent development in physical education: a national survey of policy and practice in England. Physical Education and Sport Pedagogy, $14(1), 59-72$.

Bailey, R, Pearce, G, Winstanley, C, Sutherland, M, Smith, C, Stack, N, and Dickenson, M. (2008). A systematic review of interventions aimed at improving the educational achievement of pupils identified as gifted and talented. Report. In Research Evidence in Education Library. London: EPPI-Centre, Social Science Research Unit, Institute of Education, University of London.

Bailey, R., Tan, J., and Morley, D. (2004) Talented pupils in physical education: secondary school teachers' experiences of identifying talent within the 'Excellence in Cities scheme'. Physical Education and Sport Pedagogy, 9 (2), 133-148. 
Backman, E. (2011) Friluftsliv: a contribution to equity and democracy in Swedish Physical Education? An analysis of codes in Swedish Physical Education curricula. Journal of Curriculum Studies, 43(2), 269-288.

Barton, L. (1993) Disability, empowerment and Physical Education. In J. Evans (ed) Equality, Education and Physical Education (London: Falmer Press), 43--54.

Bartram, B. (2006) Attitudes to language learning: a comparative study of peer group influences. Language Learning Journal, 33, 47- 52.

Biddle, S. Coalter, F. O’Donovan, T., Macbeath, J., Nevill, M. and Whitehead, S. (2005) Increasing demand for sport and physical activity for girls. Sport Scotland Research Report 100. Institute for Youth Sport trust. (Edinburgh: Sport Scotland).

Brock, S.J., Rovegno, I. and Oliver, K. L. (2009) The influence of student status on student interactions and experiences during a sport education unit. Physical Education and Sport Pedagogy, 14(4), $355-375$.

Cain, K. M., and Dweck, C. S. (1995) The relation between motivational patterns and achievement cognitions through the elementary school years. Merrill-Palmer Quarterly, 41, $25-52$. 
Carroll, J. B. (1981) Twenty-five years of research in foreign language aptitude. In K. C. Diller (ed), Individual Differences and Universals in Language Learning Aptitude ( Rowley, MA: Newbury House), 83--118.

CILT (2009) Language trends 2009 secondary. Full statistical report. Available online at: http://www.cilt.org.uk/home/research_and_statistics/language_trends_surveys/secondary/200 9.aspx, accessed 6 July, 2010.

Cockburn, C. and Clarke, G. (2002) Everybody is looking at you!: girls negotiating the 'femininity deficit' they incur in physical education. Women's Studies International Forum, $25(6), 651-65$.

Coleman, J.A., Galaczi, A. and Astruc, L. (2007) Motivation of UK school pupils towards foreign languages: a large-scale survey at Key Stage 3. Language Learning Journal, 35, 245281.

Dearing, R. and King, L. (2007) The Languages Review (London: Department of Education and Skills).

Department for Children, Schools and Families (2008). Identifying gifted and talented learners - getting started. (London: DCSF). Available at http://webarchive.nationalarchives.gov.uk/20110113104120/http://nationalstrategies.standard s.dcsf.gov.uk/node/288011, accessed 30 September 2011. 
Department_for Education and Employment. (2000) Excellence in cities. (London:

Department for Education and Employment).

Department for Education and Skills. (n.d) Specialist schools. Available online at:

http://webarchive.nationalarchives.gov.uk/20100113210150/standards.dfes.gov.uk/specialists

chools/, accessed 22 February, 2011.

Dismore, H., Bailey, R. and Izaki, T. (2006). Japanese and English school students' views of Physical Education: A comparative study. International Journal of Sport and Health Science, $\underline{4,74-85}$

Dörnyei, Z. (2005). The psychology of the language learner: individual differences in second language acquisition. Mahwah, NJ: Lawrence Erlbaum.

Dyson, B. (2006) Students' perspectives in Physical Education. In D. Kirk, D. Macdonald and M. O’Sullivan (eds), The Handbook of Physical Education (London: Sage), 326-436.

Evans, J. (2004) Making a difference? Education and 'ability' in physical education, European Physical Education Review, 10, 95-108. 
Fairclough, S. (2003) Physical activity, perceived competence and enjoyment during high school Physical Education. European Journal of Physical Education, 8(1), 5-18.

Flintoff, A. and Scraton, (2006) Girls and Physical Education. In D. Kirk, D. Macdonald and M. O’Sullivan (eds), The handbook of Physical Education (London: Sage), 767-783.

Freeman, J. (1998). Educating the very able: current international research. (London: The Stationery Office)

Green, K. (2009) Understanding Physical Education (London: Sage).

Evans, J. and Penny, D. (2008) Levels on the playing field: the social construction of physical "ability" in the Physical Education curriculum. Physical Education and Sport Pedagogy, 13(1), 31-47.

Gill, T. (2010) GCSE uptake and results, by school type 2002-2008. Statistics Report Series No. 19 (Cambridge Assessment: Cambridge).

Graham, S. (2004) Giving up on modern foreign languages? Students' perceptions of learning French. The Modern Language Journal 88 (2), 171-191.

Hamilton, L. (2002) Constructing pupil identity: personhood and ability. British Educational Research Journal, 28, 591 - 602. 
Horwitz, E. (1988) The beliefs about language learning of beginning university foreign language students. The Modern Language Journal, 72, 283-294.

Horwitz, E. (1999) Cultural and situational influences on foreign language learners' beliefs about language learning: a review of BALLI studies. System, 27 (4), 557-576.

JCQ (2010). Joint Council for Qualifications. GCSE, Applied GCSE and Entry Level Certificate results. Available at http://www.jcq.org.uk/national_results/gcses/, accessed 30 September 2011.

Jones, C. (2009). Parental support and the attitudes of boys and girls to modern foreign languages. Language Learning Journal, 37, 85-97

Keogh, A.F. and White, J. (2008). An in-depth study of children's concepts of intelligence. Children's Research Centre, Trinity College, Dublin.

Kerr, B.A., Colangelo, N., and Gaeth, J. (1988) Gifted adolescents' attitudes toward their giftedness. Gifted Child Quarterly, 32, 245-247. 
Kormos, J. and Csizér, K. (2008). Age-related differences in the motivation of learning

English as a foreign language: Attitudes,selves and motivated learning behaviour. Language

Learning, 58: 327-355.

Krashen, S. (1981) Aptitude and attitude in relation to second language acquisition and learning. In K.C. Diller (ed), Individual Differences and Universals in Language Learning Aptitude (Rowley, MA: Newbury House), 155-175.

Kurtz-Costes, B., McCall, R.J., Kinlaw, C.R., Wiesen, C.A. and Holland Joyner, M (2005) What does it mean to be smart? The development of children's beliefs about intelligence in Germany and the United States. Applied Developmental Psychology, 26, 217-233.

Lamb, M. (2011). Young adolescents' home background and the L2 motivational self-system. The $16^{\text {th }}$ World Congress of Applied Linguistics, Beijing Foreign Studies University, Beijing, China, 23-28 August, 2011.

Lambert, R. D. (2001). Updating the foreign language agenda. The Modern Language Journal, 85, 347-362.

Macaro, E. (2008) The decline in language learning in England: getting the facts right and getting real. Language Learning Journal, 36, 101-108. 
MacIntyre, P. and Gardner, R. (1994) The subtle effects of language anxiety on cognitive processing in the second language. Language Learning, 44, 283-305.

Manaster, G. J., Chan, J. C., Watt, C., and Wiehe, J. (1994). Gifted adolescents' attitudes toward their giftedness: a partial replication. Gifted Child Quarterly, 38, 176-178.

McLauchlan, A. (2007). Bilingual dictionaries in written language examinations: why New Zealand needs to catch up with Australia. Available at http://www.encyclopedia.com/doc/1G1-165691970.html, accessed 20 June, 2011.

Mitchell, R. (2003) Rethinking the concept of progression in the National Curriculum for Modern Foreign Languages: a research perspective. Language Learning Journal, 27, 15-23.

Nicholls, J. (1978) The development of the concepts of effort and ability, perception of academic attainment, and the understanding that difficult tasks require more ability. Child Development, 49, 800-814.

Nicholls, J. G. (1989) The competitive ethos and democratic education (Cambridge, MA, Harvard University Press).

OFSTED (2005) OFSTED Subject reports 2003/04. Physical Education in Secondary schools (London: HMI). 
O’Reilly Cavani, J. (2000) Motivation in language learning: a Glasgow snapshot. In G. Chambers (ed), Reflections on Motivation (London: CILT), 31-41.

Ortega, L. (2010). Language acquisition research for language teaching: apply, even if with caution! Keynote address, Österreichische Gesellschaft für Sprachendidaktik Conference, Innsbruck, September 23-25, 2010. Available at: http://www2.hawaii.edu/ lortega/, accessed 22 February, 2011.

Peacock, M. (2001) Pre-service ESL teachers' beliefs about second language learning: a longitudinal study. System, 29, 177-195.

Penney, D. (2000) Physical Education, sporting excellence and educational excellence. European PE Review, 6, 135- 150.

Portman, P.A. (1995) Who is having fun in physical education classes? Experiences of sixth grade students in elementary and middle schools. Journal of Teaching in Physical Education, 14, 445-53.

QCA (2006) Pupils'views on language learning (London: Qualifications and Curriculum Authority). Available online at: http://www.schoolportal.co.uk/GroupDownloadFile.asp?GroupID=338117andResourceId=2339971, accessed 22 February, 2011. 
QCA (2007a). The National Curriculum for Modern Foreign Languages. Available online at: http://curriculum.qcda.gov.uk/key-stages-3-and-4/subjects/key-stage-3/modern-foreignlanguages/index.aspx, accessed 30 September, 2011

Robinson, P. (2005) Aptitude and second language acquisition. Annual Review of Applied Linguistics, 25, 45-73.

Ryan, S., Fleming, D. and Maina, M. (2003) Attitudes of middle school students toward their physical education teachers and classes. The Physical Educator, 15(1), 22-28.

Sáfár, A. and Kormos, J. (2008) Revisiting problems with foreign language aptitude. International Review of Applied Linguistics in Language Teaching, 46 (2), 113-136.

Sawyer, M., and Ranta, L. (2001) Aptitude, individual differences and L2 instruction. In P. Robinson (ed), Cognition and Second Language Instruction (Cambridge: Cambridge University Press), 319-353.

Smith, A. and Parr, M. (2007) Young people's views on the nature and purpose of Physical Education: a sociological analysis. Sport, Education and Society, 12 (1), 37-58.

Stables, A. and Wikeley, F. (1999) From bad to worse? Pupils' attitudes to MFL at ages 14 and 15. Language Learning Journal, 20, 27-31. 
Talbot, M. (1996) Gender and the Nation Curriculum Physical Education. British Journal of Physical Education, 27 (1), 5-7.

The Guardian (2010). GCSE results 2010: exam breakdown by subject, school and gender. Available online at: http://www.guardian.co.uk/news/datablog/2010/aug/24/gcse-results2010-exam-breakdown, accessed 22 February, 2011.

Thorburn, M. and Collins, D. (2006) The effects of an integrated curriculum model on student learning and attainment. European Physical Education Review, 12 (1), 31-50.

Udvari, S.J. and Rubin, K.H. (1996) Gifted and non-selected children's perceptions of academic achievement, effort, and athleticism. Gifted Child Quarterly, 40, 211-219.

Vidal Rodeiro, C.L. (2007) Uptake of GCSE subjects 2000 - 2006. Statistics Report Series No. 4 (Cambridge: Cambridge Assessment). Available online at: http://www.cambridgeassessment.org.uk/ca/digitalAssets/182085_Stats_Report_4__Uptake_of_GCSE_subjects_2000-2006_v2.pdf , accessed 22 February, 2011.

Vidal Rodeiro, C.L. (2009) Some issues on the uptake of Modern Foreign Languages at GCSE. Statistics Report Series No. 10 (Cambridge: Cambridge Assessment). Available online at: http://www.cambridgeassessment.org.uk/ca/digitalAssets/178744_Uptake_of_Modern_Forei gn_Languages_-_Stats_Report_No_10.pdf, accessed 22 February, 2011. 
Williams, M., Burden, R., and Lanvers, U. (2002) 'French is the language of love and stuff': Student perceptions of issues related to motivation in learning a foreign language. British Educational Research Journal, 28(4), 503-549.

Williams, M., Burden, R., Poulet, G. and Maun, I. (2004) Learners' perceptions of their successes and failures in foreign language learning. Language Learning Journal, 30, 19 - 29.

Yli-Piipari, S., Watt, A., Jaakkola, T., Liukkonen, J. and Nurmi, J-E. (2009) Relationships between physical education students' motivational profiles, enjoyment, state anxiety, and selfreported physical activity, Journal of Sports Science and Medicine, 8, 328-336.

Young, D. J. (1990) An investigation of students' perspectives on anxiety and speaking. Foreign Language Annals, 23, 539-553. 


\section{Tables}

Table 1: Responses to the prospect of being identified a gifted/talented in MFL ( $N=78)$

\begin{tabular}{|c|c|c|c|c|}
\hline Word & $\begin{array}{l}\text { Number of } \\
\text { times circled }\end{array}$ & Valid Percent & $\begin{array}{l}\text { Number of } \\
\text { learners } \\
\text { identifying as best } \\
\text { summing up word }\end{array}$ & $\begin{array}{l}\text { Valid Percent of } \\
\text { all choices }\end{array}$ \\
\hline Pleased & 44 & 22.3 & 16 & 20.5 \\
\hline Proud & 43 & 21.8 & 20 & 25.6 \\
\hline Hарру & 41 & 20.8 & 19 & 24.4 \\
\hline Motivated & 14 & 7.1 & 3 & 3.8 \\
\hline Excited & 13 & 6.6 & 4 & 5.1 \\
\hline Special & 12 & 6.1 & 0 & 0 \\
\hline Not bothered & 11 & 5.6 & 10 & 12.8 \\
\hline Embarrassed & 6 & 3.0 & 1 & 1.3 \\
\hline Burdened & 2 & 1.0 & 2 & 2.6 \\
\hline Worried & 2 & 1.0 & 1 & 1.3 \\
\hline Upset & 2 & 1.0 & 1 & 1.3 \\
\hline Disappointed & 2 & 1.0 & 0 & 0 \\
\hline Other & 5 & 2.5 & 1 & 1.3 \\
\hline Total & 197 & 100 & 78 & 100 \\
\hline
\end{tabular}

Table 2: Reasons for choosing the summary word for feelings about MFL

\begin{tabular}{|l|l|l|}
\hline Reason & Frequency & Valid percent \\
\hline Sense of achievement/a good & 38 & 50.0 \\
thing & & \\
Like MFL & 8 & 10.5 \\
Would stand out & 8 & 10.5 \\
Don't care & 5 & 6.6 \\
Dislike MFL & 4 & 5.3 \\
Would spur me on & 4 & 5.3 \\
Would please parents & 2 & 2.6 \\
Too high expectations of me & 2 & 2.6 \\
Good at MFL & 1 & 1.3 \\
\hline
\end{tabular}




\begin{tabular}{|l|l|l|}
\hline Embarrassed & 1 & 1.3 \\
Other & 3 & 3.9 \\
Total & 76 & 100 \\
Missing & 2 & \\
Total & 78 & \\
\hline
\end{tabular}


Table 3: Responses to the prospect of being identified a gifted/talented in PE $(\mathrm{N}=78)$

\begin{tabular}{|l|l|l|l|l|}
\hline Word & $\begin{array}{l}\text { Number of } \\
\text { times circled }\end{array}$ & Valid Percent & $\begin{array}{l}\text { Number of learners } \\
\text { identifying as best } \\
\text { summing up word }\end{array}$ & Valid Percent \\
\hline Proud & 52 & 19.5 & 16 & 20.5 \\
Pleased & 51 & 19.1 & 11 & 14.1 \\
Happy & 48 & 18.0 & 10 & 12.8 \\
Excited & 32 & 12.0 & 10 & 12.8 \\
Motivated & 30 & 11.2 & 7 & 9.0 \\
Special & 29 & 10.9 & 8 & 10.3 \\
Embarrassed & 5 & 1.9 & 1 & 1.3 \\
Not bothered & 5 & 1.9 & 5 & 6.4 \\
Worried & 5 & 1.9 & 3 & 3.8 \\
Burdened & 3 & 1.1 & 2 & 0 \\
Upset & 1 & 0.4 & 0 & 0 \\
Disappointed & 0 & 0 & 0 & 100 \\
Other & 6 & 2.2 & 5 & \\
Total & 267 & 100 & 78 & \\
\hline
\end{tabular}


Table 4: Reasons for choosing the summary word for feelings about PE

\begin{tabular}{|l|l|l|}
\hline Reason & Frequency & Valid percent \\
\hline Like PE & 19 & 28.4 \\
Sense of achievement/a good & 12 & 17.9 \\
thing & & \\
I would stand out & 12 & 17.9 \\
Would spur me on & 8 & 11.9 \\
Good at PE & 7 & 10.4 \\
No good at PE & 5 & 7.5 \\
Dislike PE & 2 & 3.0 \\
Too high expectations of me & 2 & 3.0 \\
Total & 67 & 100 \\
Missing & 11 & \\
Total & 78 & \\
\hline
\end{tabular}

Table 5: Is being identified as gifted/talented important to you (\% of pupils for each subject)?

\begin{tabular}{llll} 
& Important & Not important & Not stated/unsure \\
\hline MFL & 56.4 & 41 & 2.6 \\
PE & 71.8 & 24.4 & 3.9
\end{tabular}

Table 6: Views of those already identified as gifted/talented by school:

Important Not important

$\underline{\text { MFL identified }}$ $68.8 \%$ $31.3 \%$

MFL not identified $54.4 \%$ $45.6 \%$

$\underline{\text { PE identified }}$ $86.2 \%$ $13.8 \%$

$\underline{\text { PE not identified }}$ $66.7 \%$ $33.3 \%$

Table 7: Cross tabulation of attitude to MFL by school

Overall Positive or Negative 


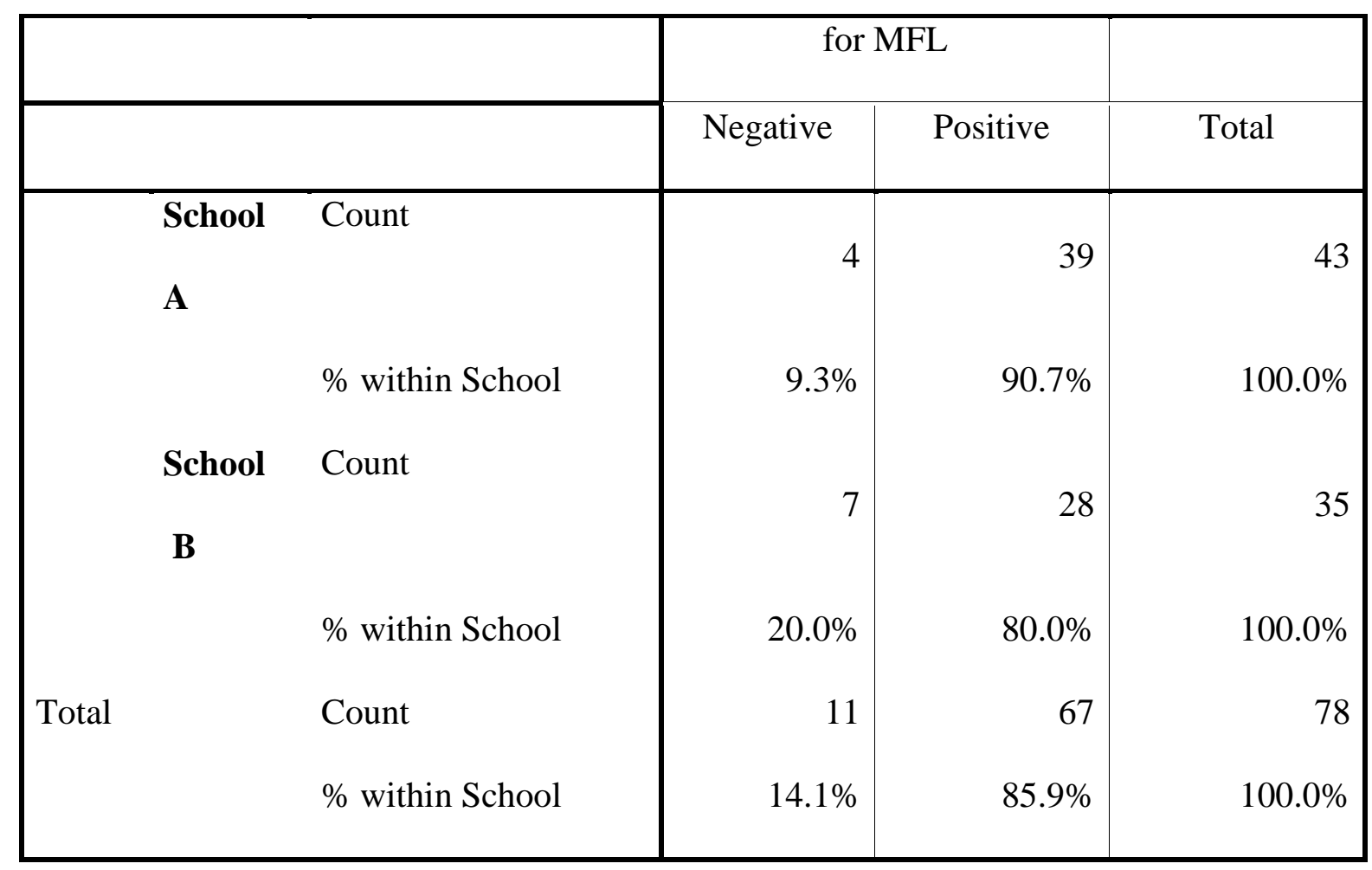

Table 8: Cross tabulation of attitude to PE by school

\begin{tabular}{|c|c|c|c|c|}
\hline & & \multicolumn{2}{|c|}{$\begin{array}{l}\text { Overall Positive or Negative for } \\
\qquad \text { PE }\end{array}$} & \multirow[b]{2}{*}{ Total } \\
\hline & & Negative & Positive & \\
\hline $\begin{array}{l}\text { School } \\
\text { A }\end{array}$ & Count & 6 & 37 & 43 \\
\hline & $\begin{array}{l}\% \text { within } \\
\text { School }\end{array}$ & $14.0 \%$ & $86.0 \%$ & $100.0 \%$ \\
\hline
\end{tabular}




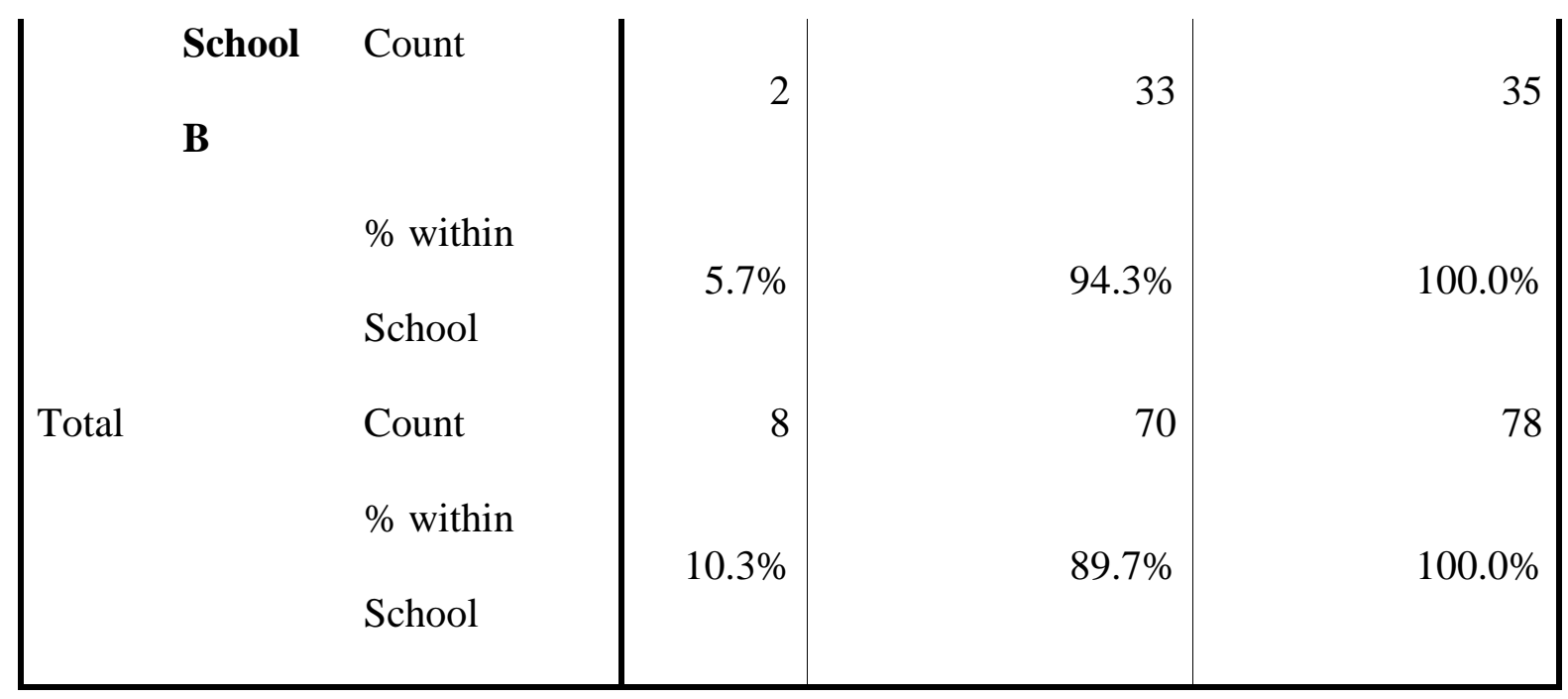


Table 9: Number of feelings circled, by school:

\begin{tabular}{|c|c|c|c|}
\hline \multicolumn{2}{|l|}{ School } & $\begin{array}{c}\text { Total Number of Feelings } \\
\text { Chosen for MFL }\end{array}$ & $\begin{array}{l}\text { Total Number of Feelings } \\
\text { Chosen for PE }\end{array}$ \\
\hline $\begin{array}{l}\text { School } \\
\text { A }\end{array}$ & Mean & 2.88 & 3.81 \\
\hline & $\mathrm{N}$ & 43 & 43 \\
\hline & Std. Deviation & 1.117 & 1.803 \\
\hline & Median & 3.00 & 4.00 \\
\hline School & Mean & 2.34 & 2.94 \\
\hline & $\mathrm{N}$ & 35 & 35 \\
\hline & Std. Deviation & 1.282 & 1.697 \\
\hline & Median & 2.00 & 3.00 \\
\hline Total & Mean & 2.64 & 3.42 \\
\hline & $\mathrm{N}$ & 78 & 78 \\
\hline & Std. Deviation & 1.216 & 1.798 \\
\hline & Median & 3.00 & 3.50 \\
\hline
\end{tabular}


Table 10: Cross tabulation of school by importance of Gifted/Talented in MFL

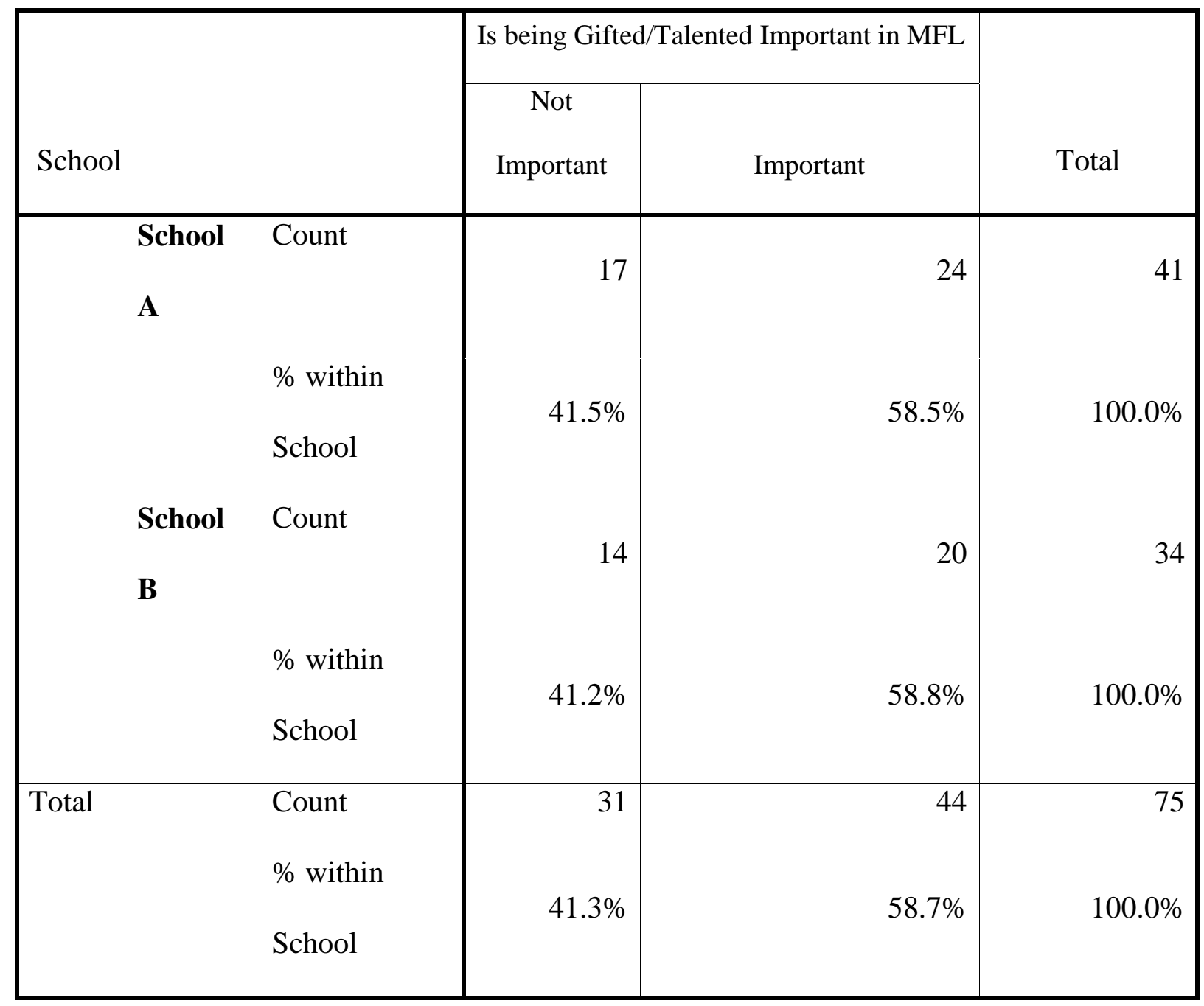


Table 11: Cross tabulation of school by importance of Gifted/Talented in PE

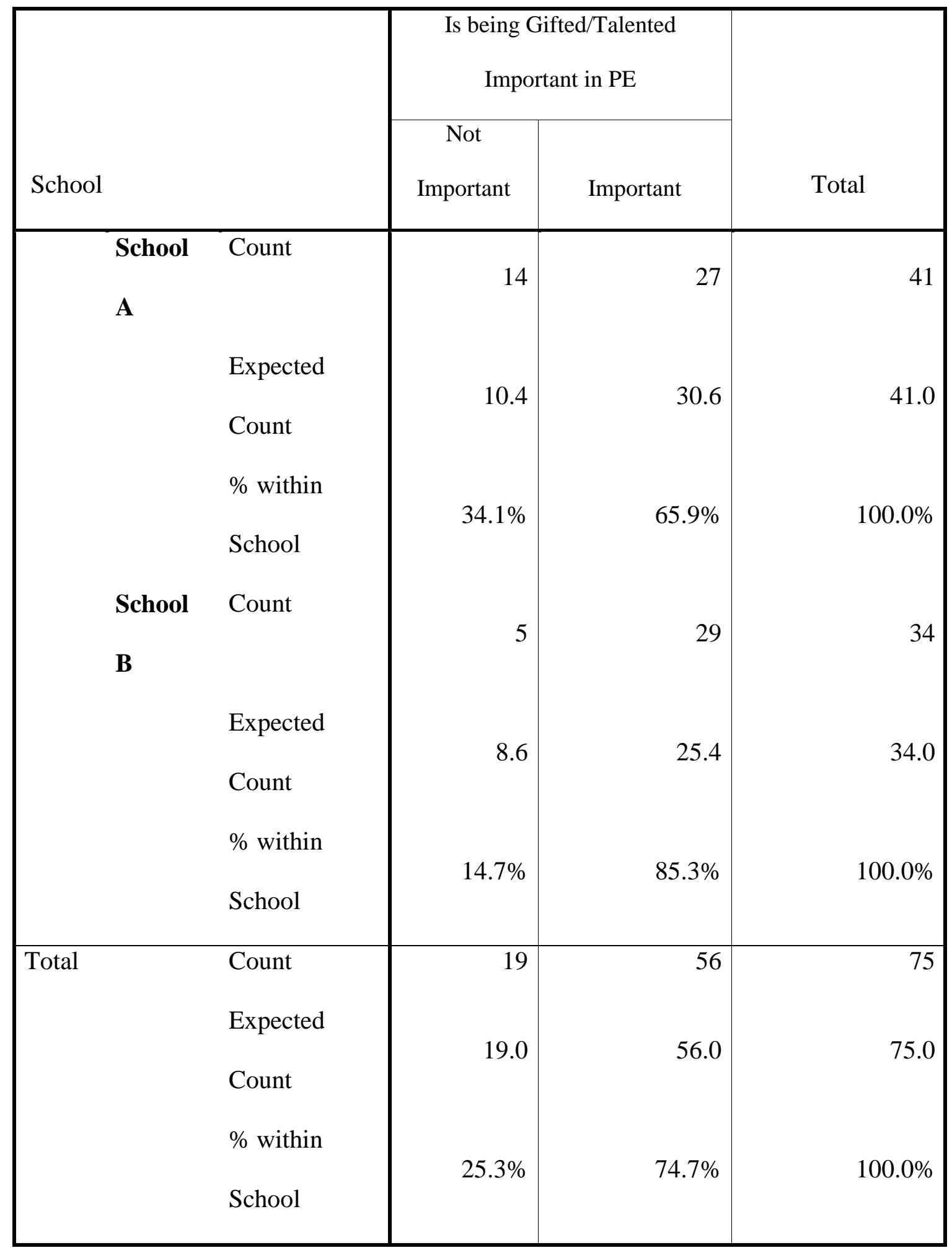

